Article

\title{
The Reinterpretation of Tetsurô Watsuji's Communitarian Thought
}

\section{Donghyun Kim}

\begin{abstract}
This paper reconsiders Tetsurô Watsuji's ethics as communitarian thought and the ontological-existential idea by observing his philosophical arguments. Watsuji uses a historicohermeneutical research scheme in considering ethics as a reflection of the place where human beings live. He comprehends the quintessence of human existence as the dual mode of individual and society in terms of it being largely based on the "betweenness" of dialectical movement between the individual and society. Hence, Watsuji's ethics can be postulated as East Asian communitarianism that stipulates the duties and attitudes of people living in East Asian societies. In addition, Watsuji seeks the genuine meaning of ethics by illuminating two concepts: fudo (climate) and ningen (human being). In so doing, he underscores the existential aspect of human existence, highlighting the social and cultural environment. Watsuji points out that Heidegger has not fully reflected on the mode of human existence with the sole concept of time; rather, unlike Heidegger, Watsuji puts forth an argument that the human existence is fundamentally influenced by a particular space and climate. Watsuji ultimately articulates that human beings can become existential subjectivity through the process of the voluntary double negation of human beings that is basically embedded in the communitarian thought. Therefore, Watsuji's philosophical thought connotes the notions of communitarianism and ontological existentialism.
\end{abstract}

Keywords: communitarianism, ontological existentialism, space double negation

(c) 2018 Donghyun Kim

https://www.kritike.org/journal/issue 23/kim december2018.pdf

ISSN 1908-7330 


\section{Introduction}

$\mathrm{L}$

afleur contends that Tetsurô Watsuji's philosophical arguments cover the difference of cultural diversity between the East and the West. ${ }^{1}$ Watsuji's philosophy is, on one hand, deeply rooted in the extensively ancient Japanese culture, primitive Buddhism, and primitive Confucianism ${ }^{2}$ while, on the other hand, influenced by Heidegger's phenomenological existentialism. ${ }^{3}$ To be sure, Watsuji's thought has dealt with the comparative analysis of Eastern and Western philosophical tradition. With his elaboration of the cross-cultural traditions of the East and West, the fundamental essence of his philosophical arguments lies in ethics based primarily on the intense reflection of human being and human existence.

Researchers' previous studies regarding Watsuji's thought vary. Some researchers argue that his idea emphasizes the Japanese emperor system. ${ }^{4}$ According to Piovesana's analysis, Watsuji's philosophical idea on ethics is absolutely socio-communitarian in nature. ${ }^{5}$ Dorsey, on the other hand, claims that Watsuji's thought is neither communitarian nor liberal, ${ }^{6}$ while Sevilla considers Watsuji as a thinker who has both liberal and communitarian thought. ${ }^{7}$ In short, Watsuji's thoughts can be demarcated into

${ }^{1}$ William Lafleur, "Reasons for the Rubble: Watsuji Tetsurô's Position in Japan's Postwar Debate about Rationality," in Philosophy East and West, 5:1 (2001), 1-25.

2 Yukichi Fukuzawa, An Outline of a Theory of Civilization, trans. by Dilworth and Hurst (Tokyo: Sophia University Press, 1973), 226.

${ }^{3}$ David A. Dilworth, "Guiding Principles of Interpretation in Watsuji Tetsurō's History of Japanese Ethical Thought: With Particular Reference to the Tension between the Sonno and Bushido Traditions," in Neglected Themes and Hidden Variations ed. by Victor Sōgen Hori and Melissa Anne-Marie Curley (Nagoya, Japan: Nanzan Institute for Religion and Culture, 2008), 101-112; Kristyna Vojtǐsková, "The Crisis of Japanese Identity in the $21^{\text {st }}$ Century and Watsuji Tetsurô's Ethics," in Asian Studies, 3:1 (2015), 129-144.

${ }^{4}$ Robert Bellah, “Japan's Cultural Identity: Some Reflections on the Work of Watsuji Tetsuro," in The Journal of Asian Studies, 24:4 (1965), 573-594; C. L. Starling, "Asserting Selflessness: The Case of Watsuji Tetsurô," in Shoin Review, 42 (2001), 33-56.

${ }^{5}$ Gino K. Piovesana, Recent Japanese Philosophical Thought 1862-1996: A Survey (London: Routledge, 1996), 141.

${ }^{6}$ Luke Dorsey, “A Japanese Ethics of Double Negation: Watsuji Tetsurô's Contribution to the Liberal-Communitarian Debate," in Otherwise: An Online Journal of Philosophy (2007), 1-13.

7 Anton Luis Sevilla, "Watsuji's Balancing Act: Changes in His Understanding of Individuality and Totality from 1937 to 1949," in Journal of Japanese Philosophy, 2 (2014), 105-134.

(c) 2018 Donghyun Kim

https://www.kritike.org/journal/issue 23/kim december2018.pdf

ISSN 1908-7330

(cc) BY-NC-ND 


\section{TETSURÔ WATSUJI'S COMMUNITARIAN THOUGHT}

four respects: totalitarian, ${ }^{8}$ pseudo-liberalist, ${ }^{9}$ communitarian, ${ }^{10}$ and neither liberal nor communitarian. ${ }^{11}$

This paper will examine not only Watsuji's philosophical standpoint imbedded mainly in communitarian thought by examining his account of ethics, but also the understanding of human existence based predominantly on ontological existentialism. Thus, this paper attempts to demonstrate that Watsuji's philosophical idea mainly involves communitarian thoughts as well as a connotation of concomitantly ontological-existential ideas.

\section{Watsuji's Communitarian Idea grounded in Ontological Existentialism}

To establish his own philosophical outlook, Watsuji attempted to directly respond to Heidegger's book, Sein und Zeit (Being and Time). Watsuji's philosophical foundation reconsiders the ontological aspect of human existence. The basic idea of his ethics embedded in humanity can be understood as "betweenness" between individuals and society so that the human existence is constituted in the dialectical movement between the two. ${ }^{12}$ Watsuji's ethics is largely based on the concept of "betweenness" founded on the principle of "the fundamental law of human beings." 13 In this sense, Watsuji's primary interest at its core lies in ethics premised on the ontological-existential foundation of human existence.

In his book Rinrigaku, Watsuji challenges the Western idea of the relationship of the individual to society. He asserts that this relationship originally derives "from the standpoint of the dual structure-both individual and social - of human existence, [it] did not advance beyond an

\footnotetext{
8 Bellah, “Japan's Cultural Identity," 573-594; Starling, "Asserting Selflessness," 33-56.

${ }^{9}$ See Fukuzawa, An Outline of a Theory of Civilization; Nao Oyama, "Some Recent Trends in Japanese Values: Beyond the Individual-Collective Dimension," in International Sociology, 5 (1990), 445-459.

${ }^{10}$ Yōtarō Kobayashi, "Japan's Individualism in Globalization Trends," in Global Communications Platform: Japanese Institute of Global Communications (9 March 2007), http://glocom.org/opinions/essays/200012 kobayashi jp individ/index.html, 13 April 2017; Piovesana, Recent Japanese Philosophical Thought, 141; Starling, "Asserting Selflessness," 33-56; Jeffrey Wu, "The Philosophy of As-Is: The Ethics of Watsuji Tetsuro," in Stanford Journal of East Asian Affairs, 1 (2001), 96-102.

${ }^{11}$ Dorsey, “A Japanese Ethics of Double Negation," 1-13; Anton Luis Sevilla, “The Communality of Creativity and the Creativity of Community: A Comparison of the Ethics of Nikolai Berdyaev and Watsuji Tetsurô," in Kritika Kultura, 15 (2010), 226-253; Sevilla, "Watsuji's Balancing Act," 105-134; Vojtǐsková, "The Crisis of Japanese Identity," 129-144.

${ }^{12}$ Dorsey, "A Japanese Ethics of Double Negation," 1-13; James M. Shields, “The Art of Aidagara: Ethics, Aesthetics, and the Quest for an Ontology of Social Existence in Watsuji Tetsuro's Rinrigaku," in Asian Philosophy, 19:3 (2009), 265-283.

${ }^{13}$ Tetsurô Watsuji, Watsuji Tetsurô's Rinrigaku, trans. by Robert Carter (Albany: State University of New York Press, 1996), 119.

(c) 2018 Donghyun Kim

https://www.kritike.org/journal/issue 23/kim december2018.pdf

ISSN 1908-7330

(c) BY-NC-ND
} 
abstraction of a single aspect." 14 In contrast to Heidegger's understanding of human existence, Watsuji proclaims that the ethics of human beings should be understood as the dual mode of individual and social of human existence. Heidegger reflects the human existence that is mainly premised on the individual aspect of human beings. Heidegger argues that, "existentially, the constancy of the self means nothing other than anticipatory resoluteness. Its ontological structure reveals the existentiality of the selfhood of the self...the self that is revealed by the reticence of resolute existence [which] is the primordial phenomenal basis for the question of the being of the 'I.'" 15 In Being and Time, Heidegger claims an individualist account of the authentic self as a genuine feature of human beings that is largely a solitary self in explicating human existence. Moreover, Heidegger argues that the "authentic potentiality-of-being" of human existence is only revealed within the context of temporality. ${ }^{16}$ Due to the finitude of human existence associated with temporality, the individualistic aspect of human existence is inevitable in that Heidegger's understanding of human existence conjures up a "voluntaristicindividualistic interpretation of authenticity." 17 Likewise, O'Connell clarifies that the authentic human being (Dasein) as a mode of human existence plays out its own free choices that are completely distinct from social activity. ${ }^{18}$ Thus, although Heidegger to some extent elucidates the social aspect of human beings as being-in-the-world along with other individuals, he primarily maintains an individualistic account of authenticity, particularly when human beings are an inexorably individualistic self. In short, whereas Heidegger seeks to elaborate humans' feature of finite individual life in his philosophy, Watsuji sketches out the essential elements of how finite human existence should be explicated in association with the circumstantial situation (i.e., space).

Watsuji critiques Heidegger for having placed too much emphasis on time and the individual, thus lacking a reflection on the importance of space and the social feature of human beings. Unlike Heidegger, Watsuji argues that human existence should be treated as revealing the dual importance of time and space. ${ }^{19}$ At the same time, Watsuji claims that the social environment of family, community, and society that surrounds human beings is important

14 Tetsurô Watsuji, Watsuji Tetsurō zenshū, Vol. 10, (Kyoto, Japan: Iwanami Shoten, 1962), vi.

${ }^{15}$ Martin Heidegger, Being and Time, trans. by John Macquarrie and Edward Robinson (Cambridge: Blackwell Publishers, Ltd, 1962), 297.

${ }^{16}$ Ibid., 296.

17 Michael Zimmerman, Eclipse of the Self: The Development of Heidegger's Concept of Authenticity (Athens, Ohio: Ohio University Press, 1981), 199.

${ }^{18}$ Derek Robert O'Connell, "Heidegger's Authenticity" (Ph.D. Dissertation., University of Illinois at Urbana-Champaign, 2015), 15.

${ }^{19}$ Ibid., vi.

(c) 2018 Donghyun Kim

https://www.kritike.org/journal/issue 23/kim december2018.pdf

ISSN 1908-7330 


\section{TETSURÔ WATSUJI'S COMMUNITARIAN THOUGHT}

in determining one's understanding of human existence. According to Watsuji, the reality of human beings is closely related to, and influenced by, their geographical and social environments. In the following passage, manifested primarily in ontological existentialism, Watsuji insists on the link between the consciousness of the ego and the sociality of human beings:

What is required for us to search for the independent consciousness of the ' $\mathrm{I}$ ' is the positing of the standpoint of the ' $\mathrm{I}$ ' as existing alone, in which there is no one else with whom the ' $\mathrm{I}$ ' shares the same consciousness. This is the case when, while alone, I look at the wall in my study and think of [my-self] that is looking at it. However, in this case if I have become conscious of the wall as a wall, then social consciousness has already intervened. What is called a wall is that 'form' society imprints on clay or sand as a specific toll (that is, as part of a house). ${ }^{20}$

In this passage, Watsuji demonstrates a communitarian idea in association with the ontological-existential underpinning of human existence that is somewhat akin to Hegel who posits a political system that rests upon both the individual and the whole. Watsuji draws out Hegel's communitarian thought of "the unity of the self and the other," 21 which consists of the fundamental structure of social ethics of human community. In Hegel's account, the nature of humans' everyday life means human agents are individuals interacting in a society. ${ }^{22}$ The characteristic of ethical actions of individuals in society is not only derived from the harmonious collectivity of all members of a community, but also requires self-conscious individuals who have shared their understanding of truth and values and who belong to the specific community. In this sense, Hegel's insistence on the "perfect balance of individuality and identification with the social whole" entails the communitarian notion of human beings who are constantly interacting with other individuals in a particular community. ${ }^{23}$ Watsuji ascertains that, in "social ethics, I can be I only by virtue of its not being isolated and independent." 24

${ }^{20}$ Watsuji, Rinrigaku, 73.

${ }^{21}$ G. W. F. Hegel, Hegel's Philosophy of Right, trans. by T. M. Knox (New York:

Oxford University Press, 1952), § 158.

22 Ibid., § 192.

${ }^{23}$ Jon Stewart, The Unity of Hegel's "Phenomenology of Spirit": A Systematic Interpretation (Evanston: Northwestern University Press, 2011), 238.

${ }^{24}$ Watsuji, Rinrigaku, 83.

(c) 2018 Donghyun Kim

https://www.kritike.org/journal/issue 23/kim december2018.pdf

ISSN 1908-7330

(cc) BY-NC-ND 
In a similar vein, Taylor, who is a communitarian heir of Hegel's moral framework on human society, contends that one's identity is exclusively defined by a fellowship of community or society to which human beings belong:

To speak of orientation is to presuppose a spaceanalogue within which one finds one's way. To understand our predicament in terms of finding or losing orientation in moral space is to take the space which our framework seeks to define as ontologically basic. The issue is, through what framework-definitions can I find my bearings in it? In other words, we take as basic that the human agent exists in a space of questions. And these are the questions to which our framework definitions are answers, providing the horizon within which we know where we stand, and what meanings things have for us. ${ }^{25}$

Taylor maintains that the activities of human beings are fundamentally determined by the commitments and identifications of social role in the specific communal society which Watsuji elucidates as 'space.' Watsuji refers to space as the particular communal society that plays an important role in shaping the moral framework of human beings. Typically, the communitarian thought invokes and underscores the role of community or space based on geographical location. In this sense, Taylor espouses Watsuji's emphasis on space, which contrasts with Heidegger's acknowledgement of time in exploring the existential feature of human beings. Watsuji's idea of the moral framework of human beings is similar to Hegel at the outset and Taylor, who succeeds Hegel's communitarian thought by recognizing the individual identity that is not simply determined by one's own transcendental idea, but by the social environment of the community. Like the Hegelian synthetic analysis of the individual and the whole, which aims to ultimately achieve the absolute spirit of the world (Geist), Watsuji asserts that human existence is to be investigated in terms of both the individual and the society. Hegel refers to the absolute spirit of the world (Geist) as the state that is essential to human beings and exercises its power over individuals. As a result, Hegel recognizes that it is important for communities to maintain the relationships between individuals and the state. Thus, Watsuji seeks to focus on everyday life and politics in favor of individual authenticity, which is only

${ }^{25}$ Charles Taylor, Sources of the Self: The Making of the Modern Identity (Cambridge, M.A.: Harvard University Press, 1989), 29.

(c) 2018 Donghyun Kim https://www.kritike.org/journal/issue 23/kim december2018.pdf ISSN 1908-7330 


\section{TETSURÔ WATSUJI'S COMMUNITARIAN THOUGHT}

possible based on the collective authenticity of communities as Hegel conceives them. ${ }^{26}$ As Mulhall and Swift write, "the identity of human self is bound up with the self's sense of the significance and meaning of the objects and situations it encounters in [social] life." 27 Over the idea of an autonomous individual, Dorsey aptly describes the main feature of communitarianism as an individual who is bound up with social influence. ${ }^{28}$ Likewise, Watsuji seemingly asserts that the social influence toward human beings is largely shaped by space.

Through his communitarian idea, Watsuji claims that the identity of human beings is entirely derived from their social environment or community or space. In addition, Watsuji's essential understanding of the notion of human existence is deeply embedded in Heidegger's ontological existentialism, even though he tries to deviate from Heidegger's thought. ${ }^{29}$ However, unlike Heidegger's commitment to the idea of the finitude of human existence based on his ontological existentialism primarily emphasizing time and the individual, Watsuji calls attention to the space and the social dimensions of human beings. In short, Watsuji's philosophical thought denotes a combination of Hegelian communitarianism and Heideggerian ontological existentialism.

\section{Watsuji's Philosophical Understanding of Ethics and Human Existence}

Watsuji's philosophical interests mainly focus on two concepts related to each other: ethics, and human existence. Watsuji begins to examine the etymological meanings of the ningen (human being, 人間) and Rinringaku (ethics) in order to explore the idea of ethics. He attempts to seek out the true meaning of ethics by explaining two concepts: fudo (climate) and ningen (human being). For Watsuji, fudo refers to nature, meaning "wind and earth...[and] the natural environment of a given land," 30 while ningen means human being. Watsuji recognizes that ethics is the study of human beings and that the locus of ethics lies in the "in-betweenness" of human beings, that is,

\footnotetext{
${ }^{26}$ Michael Gillespie, "The Search for Immediacy and the Problem of Political Life in Existentialism and Phenomenology," in A Companion to Phenomenology and Existentialism, ed. by Hubert L. Dreyfus \& Mark A. Wrathall (Oxford: Wiley-Blackwell, 2009), 532.

27 Stephen Mulhall and Adam Swift, Liberals and Communitarians (Oxford: Blackwell Publishers Ltd, 1992). 13-15.

${ }^{28}$ Dorsey, "A Japanese Ethics of Double Negation," 4.

${ }^{29}$ Sumiko Eguchi, Being a Person: The Ethics of Watsuji Tetsurô and Immanuel Kant (M.A. Thesis, The Ohio State University, 2009), 2-3. Isamu Nagami, "The Ontological Foundation in Tetsuro Watsuji's Philosophy: Kū and Human Existence," in Philosophy East and West, 31:3 (1981), 282; Starling, "Asserting Selflessness," 45-48.

${ }^{30}$ Watsuji, Tetsurō zenshū, 1.

(c) 2018 Donghyun Kim

https://www.kritike.org/journal/issue 23/kim december2018.pdf

ISSN 1908-7330
}

(c) BY-NC-ND 
person to person. ${ }^{31}$ Ningen is composed of two characters: rin, meaning "person" or "human being," and gen, meaning "space" or "between." For Watsuji, a human being is not just an isolated individual, but is also a member of a social group or the group itself: "Rinri, that is, ethics, is the order or the pattern through which the communal existence human beings rendered possible. In other words, ethics consists of the laws of social existence." 32 Offering an etymological analysis, Watsuji explains that human beings certainly pursue "fellowships" because "rin means nakama, signifies a body or a system of relations, which a definite group of persons have respect to each other." 33 In short, Watsuji reasons that humans are social or political beings in that each member of a specific society seeks out a practical connection among human beings. In this context, it can be said that Watsuji shares Aristotle's idea that "human beings are by nature political animals" because individuals are socially immersed in a society from which they cannot escape. In other words, humans are social beings who are easily vulnerable to their environment.

Yet, to a certain extent, Watsuji is not simply a thinker who embraces full-fledged communitarian ideas with regard to his reflection on the essence of human beings and human existence. He also touches upon the importance of isolated individuals by signifying the meaning of the Japanese term nin because it also connotes "person" or "human being." In Watsuji's examination of the etymology of original Chinese characters, the word ningen means "an individual human being." Literally, it means 'between persons' by stating that "on the basis of the evolving meaning of [ningen]...is the public and, at the same time, the individual human beings within it." ${ }^{34}$ Moreover, Watsuji asserts that ethics is the study of human beings (ningen), and it is inevitably perceived as an intimate relationship between the individual and the society. Accordingly, ethics is to be envisaged as "a dual focus on both individuality of the person and the sociality of human relatedness [which is] manifested in the relationships a human being is situated in." 35 Sevilla clearly sheds light on Watsuji's understanding of human existence as follows:

human existence is characterized by a dual-structure (nijûkôzô): it possesses both individuality (kojinsei) and totality (zentaisei). To try to grasp human existence from merely one of these one of these facets (as in individualism and collectivism) is folly, and to be

\footnotetext{
${ }^{31}$ Watsuji, Rinrigaku, 10.

32 Ibid., 11.

${ }^{33}$ Ibid., 10.

${ }^{34}$ Ibid., 13, 15.

35 Sevilla, "The Communality of Creativity," 234.
} 


\section{TETSURÔ WATSUJI'S COMMUNITARIAN THOUGHT}

faithful to only one of these aspects at the exclusion of the other is to go against the fundamental principle of human existence. Various commentators expound on this dual structure in order to express Watsuji's core ethical insight. ${ }^{36}$

At this point, Watsuji has emphasized both the individual human being and the human being who has an ethos of fellowship or membership in society. Thus, Watsuji's preliminary philosophical foundation prescribes the balanced dual nature of human beings, which means human beings must be steadily understood as aspects of both the individual and the social. As Watsuji argues, "neither side alone can explain human existence. But both sides exist only in negating each other. Hence it can be described as a negative dual structure." ${ }^{37}$ To be sure, Watsuji asserts this dual structure of human existence because he sees human existence as that which comprises both individuality and totality.

\section{Watsuji's Emphasis on the Notion of Double Negation}

By emphasizing the dual structure of human existence, i.e., the individual and social, one could say that Watsuji is invoking an eclectic view of the human being understood as individual human beings and individuals who belong to the community in which they live. However, from his etymological analysis of the word ningen (humang being), Watsuji's view of human existence is primarily embedded in the communitarian implication. In this context, Watsuji seemingly adopts Hegel's concept of negation (Aufhebung) in that his approach on the concept of self is closely tied to Hegel's dialectical scheme of negation. Now we can see how Watsuji brings forth the continuous process of negation of individuality and totality in the following:

An individual becomes an individual by negating emptiness (i.e., authentic emptiness) as her own fundamental source. This is the self-negation of absolute negativity. In addition to that, an individual must be subordinate to society through emptying herself, regardless of how this emptying is performed. This means that emptiness is materialized in various associations to varying degrees. Therefore, an individual returns to 'emptiness' itself, through engaging in association of whatever sort. In our attempt to comprehend wholeness itself, its essential feature was also revealed to be emptiness. Absolute wholeness is absolute negativity. Seen in this light,

36 Sevilla, "Watsuji's Balancing Act," 107.

37 Watsuji, Rinrigaku, 101-118. 
human association, inclusive of coercion, is understood to be the movement of negation of negation in which absolute negativity returns to itself through its own self-negation. ${ }^{38}$

Although Watsuji places greater emphasis on the role of individuality that is indispensable to the community, ${ }^{39}$ he appears to privilege totality over individuality. In this sense, the absolute negation of human beings between the individuals and the society is in accordance with Hegel's concept of the dialectical relationship of the individual and the whole. At first glance, Watsuji's assertion of the importance of the individuals is also parallel with that of the society; however, he still emphasizes the role of society by demonstrating the concept of "double negation." In other words, Watsuji's rejection of the self through the double negation leads to the idea that human beings depend upon society for their survival. ${ }^{40}$ In a sense, the idea that individuals should relinquish their right in order to carry out their obligatory role as a part of the whole or a member of certain society could be regarded as a communitarian indication. Moreover, Watsuji's emphasis of the communitarian idea is akin to that of ultra-rationalism or totalitarian thought, according to which the individual must abandon one's free and autonomous self in order for a community to exist. ${ }^{41}$ the community by negating oneself, and submerging individuality in totality. ${ }^{42}$ Here, Watsuji's concept of double negation in accordance with the emphasis of the particular environment does nothing but ascertain the importance of particularistic culture of Japan. Thus, his moral framework is primarily embedded in the culturally relativistic point of view of Japan.

In addition, Watsuji discusses the role of the whole compared to the individual as especially important by providing the following example of a family: "If parents stop behaving as parents, children as children, wives as wives, and husbands as husbands, then the family will be dissolved." 43 Thus, the family can only exist through the members who constitute it. Watsuji concurs with Hegel's idea of the family as the basic unit of human existence. ${ }^{44}$ In other words, the structure of human existence is expressed as the organizations or membership of the community that essentially arises from family. Accordingly, it can be said that Watsuji's understanding of ethics depicts a communitarian idea parallel with Hegel's notion of ethical life (sittlichkeit). Hegel elucidates the ethical life as follows:

${ }^{38}$ Ibid., 116-117.

39 Sevilla, "Watsuji's Balancing Act," 111.

${ }^{40}$ Sevilla, "The Communality of Creativity," 245.

${ }^{41}$ Bellah, "Japan's Cultural Identity," 590-591; Starling, "Asserting Selflessness," 40-41.

42 Dorsey, "A Japanese Ethics of Double Negation," 12.

${ }^{43}$ Watsuji, Rinrigaku, 89.

${ }^{44}$ Hegel, Philosophy of Right, §§ 33, 159.

(c) 2018 Donghyun Kim https://www.kritike.org/journal/issue 23/kim december2018.pdf ISSN 1908-7330 


\title{
136 TETSURÔ WATSUJI'S COMMUNITARIAN THOUGHT
}

\begin{abstract}
Ethical life is the Idea of freedom in that on the one hand it is the good become alive - the good endowed in selfconsciousness with knowing and willing and actualized by self-conscious action - while on the other hand selfconsciousness has in the ethical realm its absolute foundation and the end which actuates its effort. Thus ethical life is the concept of freedom developed into the existing world and the nature of self-consciousness. ${ }^{45}$
\end{abstract}

In Hegel's account, individuals in a particular political community who are largely exposed to its customs and conventions entirely follow the specific ethical principle of this society. Human beings are predominantly embedded in the specific ethical value associated with the ethical life derived from a particular community or society. According to Thompson, Hegel maintains that the moral life of individuals is "completely bound up with their participation" in a particular community. ${ }^{46}$ The Hegelian notion of ethical life refers to the concrete ethical value of human beings who put into effect the commitment of membership in a particular community.

For Watsuji, everywhere, we are determined by collectives - from a small organization of people, such as friendship and family, to a large organization of individuals such as large corporations, nations, and even the global village. Hence, this kind of philosophical argument displays the moral framework of communitarianism derived from the society, not the individual. Watsuji asserts his eclectic view on human beings; he writes: "society must be a community that exists in accordance with and among its members. But it is not communal because of its being universal. Conversely, it is universal because of its being communal. The state of a group becomes a phenomenon common to individuals, because it coerces individuals as that which commands." 47 Moreover, in this context, it can be said that his philosophical stance is closely tied to the fundamental communitarian idea of each member of society belonging to a specific practical interconnection among human beings. Watsuji considers all human beings to be vulnerable to the geographical land, topography, and climate in which they live, so that the mode of human beings is inescapably affected by environment. Thus, Watsuji's moral philosophy culminates in a communitarian ethics of the Japanese family system.

45 Ibid., § 142.

${ }^{46}$ Janna Thompson, Justice and World Order: A Philosophical Inquiry (London: Routledge, 1992), 113.

${ }^{47}$ Ibid., 111-112.

(C) 2018 Donghyun Kim

https://www.kritike.org/journal/issue 23/kim december2018.pdf

ISSN 1908-7330

(c) ) BY-NC-ND 


\section{Conclusion}

Watsuji's ethics primarily originates from a traditional human relationship of obligations and attitudes in the communities of the East. His idea entails the communitarianism that stipulates the traditional human relationship of human beings living in the East Asian community. He considers ethics to be the activity of human beings that is primarily affected by fudo (climate) and space (i.e., its geographical location), so that every society produces its specific culture. In other words, Watsuji's moral framework pinpoints a communitarian idea, signifying that fudo (climate) and space are closely related to the social and cultural aspect of human beings. Watsuji also presupposes the ontological existentialism of Heidegger's commitment to idea of the finitude of human existence in emphasizing the notions of space and the social dimensions of human beings. At the center of Watsuji's philosophical interests lie two concepts related to each other: ethics and human existence. Watsuji examines the ningen (human being) and Rinringaku (ethics) so as to explore the true meaning of ethics. He recognizes ethics as the intense reflection of how human beings exist for survival. Watsuji also highlights the role of space in shaping the ontological existential aspect of human existence. For Watsuji, ethics is the study of human beings; it lies in the "in-betweenness" of human beings. ${ }^{4}$ Accordingly, Watsuji affirms that ethics as the study of human beings (ningen) is inexorably the interactional relationship between individual and the society. Watsuji has emphasized both the individual human being and the human being who has an ethos of fellowship or membership in society. Moreover, his preliminary philosophical foundation prescribes the dual nature of human beings: human beings must be steadily understood as aspects of both the individual and the social. It can be said that Watsuji understands ethics as demonstrating the communitarian idea that is parallel with Hegel's notion of ethical life (sittlichkeit). In this sense, Watsuji's moral philosophy finally ends with a communitarian ethics of the particular Japanese family system. Thus, his communitarian thought can also be equally considered as an ontological-existential ethics based exclusively on Japanese culture.

Institute of Public Policy \& Administration, Chung-Ang University, South Korea

${ }^{48}$ Ibid., 10.

(c) 2018 Donghyun Kim

https://www.kritike.org/journal/issue 23/kim december2018.pdf

ISSN 1908-7330

(cc) BY-NC-ND 


\section{TETSURÔ WATSUJI'S COMMUNITARIAN THOUGHT}

\section{References}

Bellah, Robert N., "Japan's Cultural Identity: Some Reflections on the Work of Watsuji Tetsuro," in The Journal of Asian Studies, 24:4 (1965).

Dilworth, David A., "Guiding Principles of Interpretation in Watsuji Tetsurō's History of Japanese Ethical Thought: With Particular Reference to the Tension between the Sonno and Bushido Traditions," in Neglected Themes and Hidden Variations, ed. by Victor Sōgen Hori and Melissa Anne-Marie Curley (Nagoya, Japan: Nanzan Institute for Religion and Culture, 2008).

Dorsey, Luke, “A Japanese Ethics of Double Negation: Watsuji Tetsurô's Contribution to the Liberal-Communitarian Debate," in Otherwise: An Online Journal of Philosophy, (2007).

Hegel, G. W. F., Hegel's Philosophy of Right, trans. by T. M. Knox (New York: Oxford University Press, 1952).

Heidegger, Martin, Being and Time, trans. by John Macquarrie and Edward Robinson (Cambridge: Blackwell Publishers, Ltd, 1962).

Eguchi, Sumiko, Being a Person: The Ethics of Watsuji Tetsurô and Immanuel Kant (M.A. Thesis, The Ohio State University, 2009).

Fukuzawa, Yukichi, An Outline of a Theory of Civilization, trans. by Dilworth and Hurst (Tokyo: Sophia University Press, 1973).

Gillespie, Michael, "The Search for Immediacy and the Problem of Political Life in Existentialism and Phenomenology," in A Companion to Phenomenology and Existentialism, ed. by Hubert L. Dreyfus \& Mark A. Wrathall (Oxford: Wiley-Blackwell, 2009).

Kobayashi, Yōtarō, "Japan's Individualism in Globalization Trends," in Global Communications Platform: Japan Institute of Global Communications (9 March 2007), http://glocom.org/opinions/essays/200012 kobayashi jp individ/in dex.html, 13 April 2017.

Lafleur, William, "Reasons for the Rubble: Watsuji Tetsurô's Position in Japan's Postwar Debate about Rationality," in Philosophy East and West, 5:1 (2001).

Mulhall, Stephen and Adam Swift, Liberals and Communitarians (Oxford: Blackwell Publishers Ltd, 1992).

Nagami, Isamu, "The Ontological Foundation in Tetsuro Watsuji's Philosophy: Kū and Human Existence," in Philosophy East and West, 31:3 (1981).

O'Connell, Derek Robert, "Heidegger's Authenticity," (Ph.D. Dissertation, University of Illinois at Urbana-Champaign, 2015).

Oyama, Nao, "Some Recent Trends in Japanese Values: Beyond the Individual-Collective Dimension," in International Sociology 5 (1990).

(c) 2018 Donghyun Kim

https://www.kritike.org/journal/issue 23/kim december2018.pdf

ISSN 1908-7330

(cc) BY-NC-ND 
Piovesana, Gino K., Recent Japanese Philosophical Thought 1862-1996: A Survey (London: Routledge, 1996).

Sevilla, Anton Luis, "The Communality of Creativity and the Creativity of Community: A Comparison of the Ethics of Nikolai Berdyaev and Watsuji Tetsurô," in Kritika Kultura, 15 (2010).

"Watsuji's Balancing Act: Changes in His Understanding of Individuality and Totality from 1937 to 1949," in Journal of Japanese Philosophy, 2 (2014).

Shields, James M., "The Art of Aidagara: Ethics, Aesthetics, and the Quest for an Ontology of Social Existence in Watsuji Tetsuro's Rinrigaku," in Asian Philosophy, 19:3 (2009).

Starling, C. L., "Asserting Selflessness: The Case of Watsuji Tetsurô," in Shoin Review, 42 (2001).

Stewart, Jon, The Unity of Hegel's "Phenomenology of Spirit": A Systematic Interpretation (Evanston: Northwestern University Press, 2011).

Taylor, Charles, Sources of the Self: The Making of the Modern Identity, (Cambridge, M.A.: Harvard University Press, 1989).

Thompson, Janna, Justice and World Order: A Philosophical Inquiry (London: Routledge, 1992).

Vojtřsková, Kristyna, "The Crisis of Japanese Identity in the 21 ${ }^{\text {st }}$ Century and Watsuji Tetsurô's Ethics," in Asian Studies, 3:1 (2015).

Watsuji, Tetsurô, Watsuji Tetsurō zensh̄̄ 『和辻哲郎全集』Vol. 10，(Kyoto, Japan: Iwanami Shoten, 1962). Watsuji Tetsurô's Rinrigaku, trans. by Robert Carter (Albany: State University of New York Press, 1996).

Wu, Jeffrey, "The Philosophy of As-Is: The Ethics of Watsuji Tetsuro," in Stanford Journal of East Asian Affairs, 1 (2001).

Zimmerman, Michael, Eclipse of the Self: The Development of Heidegger's Concept of Authenticity (Athens, Ohio: Ohio University Press, 1981).

(C) 2018 Donghyun Kim

https://www.kritike.org/journal/issue 23/kim december2018.pdf

ISSN 1908-7330 